\title{
Prevalence of Sexual Harassment in a Faith-Based Institution of Higher Learning in South-Western Nigeria
}

\author{
Okondu Ogechukwu Emmanuel ${ }^{1,4}$, John Nwabiani ${ }^{1}$, Afolabi Rachael Ayomide ${ }^{1}$, Atulomah Nnodimele Sonny ${ }^{1}$, \\ Ikonta Peter $\mathrm{C}^{2}$, Okafor Ukamaka Gladys ${ }^{3}$, Uchenna Loveth Ifediora ${ }^{4}$, Chigeru Chinyere Florence ${ }^{2}$, Iloma \\ Unwobuesor Richard ${ }^{5}$, Khadija Abubakar ${ }^{6} \&$ Okondu Emmanuel Confidence $^{7}$ \\ ${ }^{1}$ Department of Public Health, Babcock University, Ilishan-remo, Ogun State, Nigeria \\ ${ }^{2}$ Student Support Center, Babcock University, Ilishan-remo, Ogun State, Nigeria \\ ${ }^{3}$ Pharmacists Council of Nigeria, Lagos, Nigeria \\ ${ }^{4}$ Faculty of Education, Department of Human Kinetics and Health Education, Nnamdi Azikiwe, Nigeria \\ ${ }^{5}$ Rivers State College of Sciences and Management Technology, Port-Harcourt, Nigeria \\ ${ }^{6}$ University of Sheffield, South Yorkshire, England, United Kingdom \\ ${ }^{7}$ Jotna Nigeria Limited, 12 Akinwande Street, Off Badagry Express way, Lagos, Nigeria \\ Correspondence: Okondu Ogechukwu Emmanuel, Department of Public Health, Babcock University, \\ Ilishan-remo, Ogun State, Nigeria. Tel: 234-708-577-9565. E-mail: emmaokondu@gmail.com
}

Received: July 25, 2020 Accepted: September 10, 2020 Online Published: October 30, 2020

doi:10.5539/gjhs.v12n13p1 URL: https://doi.org/10.5539/gjhs.v12n13p1

\begin{abstract}
Tertiary institutions are ivory towers where academic and moral excellences are expected to be promoted. However, it has become where sexual harassment is a common deviant practice. This study aimed to determine the knowledge and prevalence of sexual harassment among college students in a private institution in Ogun state, Nigeria. The study employed a cross-sectional survey design to enroll 394 college students across the undergraduate levels of the university, using a 22 -item self-administered validated instrument by a multi-stage sampling procedure. Demographic characteristics, knowledge and prevalence of college students on sexual harassments were measured. The mean age of respondents was $18.84 \pm 1.833$ years, with majority $(71 \%)$ being between ages $15-19$, and $70 \%$ being females. About $39 \%$ and $38 \%$ respectively confirmed they have been victims of sexual harassment or know friends that have been harassed sexually. Level of knowledge on sexual harassment was $3.90 \pm 0.866$ and prevalence of sexual harassment was $4.88 \pm 3.194$ computed on a mean and standard deviation scale, translate to a prevalence score of $40.67 \%$. Prevalence of Sexual Harassment was high among college student even though they had good Knowledge. A more proactive measures needs to be put in place to curb the menace in a Christian own institution of higher learning.
\end{abstract}

Keywords: Sex for grade, sexual harassment, college students, faith-based institutions

\section{Introduction}

Sexual harassment is an epidemic throughout global higher education systems and impact individuals, groups and entire organizations in profound ways. Precarious working conditions, hierarchical organizations, a normalization of gender-based violence, toxic academic masculinities, a culture of silence and a lack of active leadership are all key features enabling sexual harassment (Bondestam \& Lundqvist, 2020). Sexual harassment is no more a new social phenomenon in Nigerian tertiary institutions. It has become a common deviant practice in most of the tertiary institutions in Nigeria (Suleiman, 2017). Reports have it that sexual harassment in education is higher in countries with weak educational systems, low levels of accountability, high level of poverty and gender inequality. It was further discovered that sexual harassment is more prevalent in institutions where educators are poorly trained, underpaid and under sourced (Beninger, 2013; Lynch, 2013; Sharma, 2013). Tertiary institutions are ivory towers where academic and moral excellences are expected to be promoted. Similarly, in his view, (Obasanjo, 2012), opined that education must foster in the individual those values which make for good citizenship such as honesty, selflessness, tolerance, dedication, hard work, personal integrity, all of which provide the rich soil from which good leadership is produced. 
Sexual harassment is a frequent situation that occurs all over the world, in places such as institutions, schools, workplace environment and within the family (Lei et al., 2019). Studies around the globe has shown an alarming prevalence rate of SH among university students which vary considerably across studies, ranging from about $20 \%$ in Israel, the Netherlands and Taiwan (Attar-Schwartz, 2009; Timmerman, 2005; Wei \& Chen, 2012) to as high as 90\% in the U.S. (Lichty \& Cambell, 2012; Ormeod \& Perry, 2008). Subsequently in Africa, few studies had also shown a high incidence of sexual harassment among university students. For instant, Ogbonnaya and Emma-Echiegu (2017) (Ogbonnaya, Ogbonnaya, \& Emma-Echiegu, 2011) reported a prevalence of $67 \%$ among students attending University of Malawi while another study in South Africa reported that $30 \%$ of female students were raped and sexually harassed by male students and teachers in high schools [Smit \& Du Plessis, 2011]. Earlier studies from educational institutions in Nigeria had reported range from 67 to $99 \%$ on various forms of sexual harassment in public institutions (Imonike, Aluede \& Idogho, 2012; Eom et al., 2015). Furthermore, studies had also shown a high prevalence among female respondents (Petersen \& Hyde, 2013; Rosenthal, Smidt \& Freyd, 2016; Bucchianeri et al., 2014) while other studies found different prevalence between males and females depending on the type of harassment considered (Chiodo et al., 2009; Olaleye \& Ajuwon, 2012).

Consequently, the United Nations Member States in 2015 as a universal call to action to end poverty, protect the planet and ensure that all people enjoy peace and prosperity by 2030, posit that the Sustainable Development Goals (SDGs), also known as the Global Goals would be adopted by the world leaders at the United Nations to address problems affecting the world, such as goal 1 which says no poverty; goal 3 which says good health and well-being and goal 4 which says quality education with the aim of bringing development through improving people's social and economic conditions, more especially in the world's poorest nations. However, with the high incidence of sexual harassment of students in tertiary institutions and its consequences on the victims, the issue of sexual harassment is likely to be a serious threat to achieving good quality education in Nigeria.

Therefore, it is pertinent to note that sexual harassment is a threatening social phenomenon in Nigerian educational sector; which has severe psychological and social consequences on the victims as well as economic and political consequences on the nation in achieving sustainable development (Suleiman, 2017). Thus, it is imperative as a matter of urgency and national interest, to arrest the problem of sexual harassment of students in private tertiary institutions in Nigeria where the problem is under researched. This study was therefore proposed to determine the knowledge and prevalence of sexual harassment among college students in a private institution in Ogun state, Nigeria.

\section{Methods}

\subsection{Study Design}

This study adopted a cross-sectional design using multi-stage sampling technique to select respondents to partake in the study. A validated questionnaire which was self-administered for data collection.

\subsection{Description of Study Area and Population}

Babcock University is a first class Seventh-Day Adventist institution, building servant leaders for a better world. The university consists of 9 schools and one college which are; School of Agricultural sciences, School of Basic and Applied Sciences, School of Computing and Engineering Sciences, School of Education and Humanities, School of Law and Security studies, School of Nursing Sciences, School of Public and Allied Health, Babcock Business School, School of Post Graduate Studies and Benjamin Carson College of Medicine. The study population for this study consisted of male and female undergraduate students in Babcock University.

\subsection{Data Collection and Analysis}

Data was collected using a close ended questionnaire. Instrument was pretested with $10 \%$ of the sample size from a population with similar characteristics but not the actual population. The test-re-test technique was used to determine reliability of the instrument. Errors and omissions were corrected based on the pre-test before the final questionnaire for the study was produced. Cronbach's Alpha test for internal consistency was 0.765. Ethical approval was obtained from the Babcock University Health Research Ethical Committee before commencement of the research. Instrument was distributed using trained research assistants and to ensure anonymity of respondent's, personal identifiers were not requested. Data from this research was analyzed using IBM SPSS Statistics version 25 , as a coding guide to generate descriptive and inferential statistics and to analyze the frequency of the levels.

\section{Results}

The study results indicates that the mean age of respondents was $18.84 \pm 1.833$ years old and most (70\%) of the age distribution were between 15-19 years, indicating a young population, risk of underage and age of consensual sex 
among respondents. Majority of the respondents were female (70.6\%) compared to $29.4 \%$ male respondents. Almost (81\%) the entire study population were predominantly Christians and $18 \%$ Muslims. (See Table 1 )

Table 1. Socio-demographic characteristics of the respondents

\begin{tabular}{|c|c|c|}
\hline \multirow{2}{*}{ Socio-demographic variables for consideration } & \multicolumn{2}{|c|}{ Respondents in this study; $\mathrm{N}=394$} \\
\hline & Frequency (n) & Percentage $(\%)$ \\
\hline \multicolumn{3}{|l|}{ Age (in years) $\overline{\mathrm{x}} \mathrm{SD} 18.84 \pm 1.833$} \\
\hline $15-19$ & 280 & 71.1 \\
\hline $20-24$ & 107 & 27.2 \\
\hline $25-29$ & 7 & 1.8 \\
\hline \multicolumn{3}{|l|}{ Gender } \\
\hline Male & 116 & 29.4 \\
\hline Female & 278 & 70.6 \\
\hline \multicolumn{3}{|l|}{ Religion } \\
\hline Christianity & 319 & 81 \\
\hline Islam & 71 & 18 \\
\hline Traditional & 4 & 1 \\
\hline \multicolumn{3}{|l|}{ Marital Status } \\
\hline Single & 374 & 94.9 \\
\hline Engaged & 17 & 4.3 \\
\hline Married & 3 & 0.8 \\
\hline \multicolumn{3}{|l|}{ Level } \\
\hline 100 & 22 & 5.6 \\
\hline 200 & 155 & 39.3 \\
\hline 300 & 140 & 35.5 \\
\hline 400 & 62 & 15.7 \\
\hline 500 & 15 & 3.8 \\
\hline
\end{tabular}

Majority of the respondents (70.6\%) affirms that sexual harassment occurs in this institution while 39\% confirms that they had been sexually harassed in the institution before. Additionally, $38.8 \%$ of the respondents affirm to have close friends who had been harassed in this institution before. Furthermore, $19.8 \%$ of the respondents affirm to have been sexually harassed in exchange for a good grade in the past, likewise about $40.1 \%$ confirms to having had experience of inappropriate or offensive comments made about their body by either a lecturer, staff or student. Almost half (44.7\%) of the respondents had experience sexual gestures been made at them in the institution while $25.4 \%$ had been given money in the past to seduce them into having sex. About $41.1 \%$ of the respondents affirms to their sexual organ been looked at without their knowledge while more than half $(58.4 \%)$ confirms other individuals brushing their body against theirs an unwelcomed manner. Less than half (43.1\%) of the respondents revealed that people had often told sexual jokes or stories that were insulting or offensive to them while about $40.1 \%$ also concur to a lecturer, staff or student made inappropriate or offensive comments about someone else's body or appearance in the institution. Only $27.2 \%$ of the respondents had a lecturer, staff or student continued to ask them to go out, have drinks or have sex even though they reject (See Table 2) 
Table 2. Prevalence of sexual harassment among respondents $N=394$

\begin{tabular}{|c|c|c|c|}
\hline \multirow{2}{*}{$\mathrm{S} / \mathrm{N}$} & \multirow{2}{*}{ Statements for Consideration } & YES & NO \\
\hline & & $\mathrm{F}(\%)$ & $\mathrm{F}(\%)$ \\
\hline 1 & Have you ever been sexually harassed in this institution? & $154(39.1)$ & $240(60.9)$ \\
\hline 2 & Does sexual harassment occur in this institution? & $278(70.6)$ & $116(29.4)$ \\
\hline 3 & Have any of your close friends been harassed in this institution? & $153(38.8)$ & $241(61.2)$ \\
\hline 4 & $\begin{array}{l}\text { Have you ever been sexually harassed in exchange for a good grade / pass mark in } \\
\text { this institution? }\end{array}$ & $78(19.8)$ & $316(80.2)$ \\
\hline 5 & $\begin{array}{l}\text { Has a lecturer, staff or student ever made inappropriate or offensive comments about } \\
\text { your body or appearance in this institution? }\end{array}$ & $158(40.1)$ & 236(59.9) \\
\hline 6 & People make sexual gestures at you in this institution? & $176(44.7)$ & $218(55.3)$ \\
\hline 7 & Has someone attempted to give you money to seduce you into having sex? & $100(25.4)$ & 294(74.6) \\
\hline 8 & $\begin{array}{l}\text { Has someone attempted to view, see or look at your sexual organ without your } \\
\text { knowledge? }\end{array}$ & $162(41.1)$ & 232(58.9) \\
\hline 9 & Has someone brushed his/her body against your own in an unwelcomed manner? & $230(58.4)$ & $164(41.6)$ \\
\hline 10 & $\begin{array}{l}\text { Has anyone told sexual jokes or stories that were insulting or offensive to you in this } \\
\text { institution? }\end{array}$ & $170(43.1)$ & $224(56.9)$ \\
\hline 11 & $\begin{array}{l}\text { Has a lecturer, staff or student ever made inappropriate or offensive comments about } \\
\text { someone else's body or appearance in this institution? }\end{array}$ & $158(40.1)$ & 236(59.9) \\
\hline 12 & $\begin{array}{l}\text { Has a lecturer, staff or student continued to ask you to go out, have drinks or have sex } \\
\text { even though you said, "No"? }\end{array}$ & $107(27.2)$ & 287(72.8) \\
\hline
\end{tabular}

The respondent's level of knowledge regarding sexual harassment was measured on a 5-points rating scale with a mean score of $3.90 \pm 0.866$ translated to level of knowledge prevalence of $78 \%$. Indicating good knowledge on sexual harassment. Prevalence of sexual harassment was measured on a 12-points rating scale showed a mean score of $4.88 \pm 3.194$ translated to a prevalence of sexual harassment of $40.67 \%$. (See Table 3 )

Table 3. Descriptive Statistics of Composite Scores in this Study

\begin{tabular}{lllcccc}
\hline \multirow{2}{*}{ Variables } & \multirow{2}{*}{ Reference Point Scale Measure } & \multicolumn{3}{c}{ Respondents in this study, N=394 } & \multicolumn{2}{c}{ Prevalence performance } \\
\cline { 3 - 4 } & & $\overline{\mathrm{x}}$ & $\mathrm{S} . \mathrm{E}$ & $\pm \mathrm{SD}$ & & $(\%)$ \\
\hline Knowledge & 5 & 3.90 & 0.044 & 0.866 & 78 \\
Prevalence & 12 & 4.88 & 0.161 & 3.194 & 40.67 \\
\hline
\end{tabular}

\section{Discussion}

The demographic characteristics; with emphasis to age of respondents indicates that the perpetrators may be dealing with under age due to the age bracket constituted in this study, in contrast perpetration of non-consensual sex conducted by Olaleye and Ajuwon (2012) reveled that their respondents were between the ages of 16-35 years, with the most abused to be within age bracket 21-25 years. The disparities in prevalence might be as a result of the study location because this study was done among Babcock university students, a faith-based private tertiary institution where they are mostly young people compared to their counterpart in public institutions while the other study was conducted among students of The Polytechnic Ibadan. Subsequently, there were more female respondents than male which is similar to the findings of Bastiani, Romito and Saurel-Cubizolles (2018) among Italian university students which might be as a result of female gender dominating the world's population.

The result of this study indicated that majority of the respondents had a high level of knowledge regarding $\mathrm{SH}$, a figure comparable to that observed in a study by Menon, Sanjobo, Lwatula, Nkumbula, Zgambo, Musepa et al. (2014). This could be attributed to the fact that sexual harassment occurs on campus and most people might have experienced or come across or heard about someone that had experienced it. More than three quarter of the 
respondents affirms that SH can take place anywhere, a victim or perpetrator can be any gender, can have psychological effect on the victim and perpetrator does not have to be an opposite gender. Our findings are constant with existing literature where it was observed that majority of their respondents agreed that SH can occur anywhere and does not have to be an opposite gender (Arya \& Arya, 2019; Bendixen \& Kennair, 2017; Espelage, Hong, Rinehart, \& Doshi, 2016; Gewirtz-Meydan \& Finkelhor, 2019); the perpetrator can be any gender and relatively someone the victim knows (AAUW, 2011). Similarly, it was also reported that the physiological effect of $\mathrm{SH}$ on victim is enormous which include their desire to discontinue their schooling while for others it increased their fear of being withdrawn especially if their peers or parents came to hear of any incident (Bendixen \& Kennair, 2017; Goodman et al., 2020). The similarities observed in these results shows that SH is a menace that has eaten deep into our society both in the developed and developing countries making the young and old aware of its prevalence

Too often, these negative emotional effects take a toll on students' education, resulting in decreased productivity and increased absenteeism from school. Additionally, more than half of the respondents disagreed that a person's age determines if he/she would be sexually harassed, likewise, several literatures have proven it to be accurate that no matter how old or young you are, there is a likelihood that you can be sexually harassed (Plummer, 2006; Schaeffer, Leventhal, \& Asnes, 2011; Mezie-Okoye \& Alamina, 2014; Gaba, 2010).

Majority of the respondents affirms that SH occur in this institution while one quarter attest that they or their close friends had been harassed before as observed by a research among female undergraduate students in Port-Harcourt (Imonikhe, Aluede, \& Idogho, 2012). Few of the respondents further confirms that they have been sexually harassed in exchange for good grade in the past. The finding also supports the views from researches that opined sex in exchange for grades are found in tertiary institutions of Nigeria (Oni, Tshitangano, \& Akinsola, 2019; Dastile, 2004). Consistent with previous studies (Sharma, 2013; Olaleye, \& Ajuwon, 2012; Bastiani, Romito, \& Saurel-Cubizolles, 2018; Ogunbameru, 2006; Effa, Okokon, Nwagbara, \& Bello, 2012; Kullima et al., 2010), the results of this study revealed the common forms of sexual harassment experienced by the students. These includes inappropriate or offensive comments about their body or appearance, unwanted sexual gestures, attempted viewing of sexual organ, unnecessary body contact, sex-related jokes, sex-related comments about peoples' appearance and constant pressure on sexual advances. The implication of this is that it weakens the educational system and continually traumatize the victims, thereby having an impact on their quality of life.

The prevalence of SH found in this study was $40.67 \%$ which compares favourably with what was obtained in Calabar at $44 \%$ (Iliyasu et al., 2011) and Port-Harcourt at 46.7\% (Alexander, 2012) where the location is in the Southern part of Nigeria, while in the Northern Nigeria the prevalence was much lower, $13.8 \%$ in Maiduguri (Menick, 2002) and 22.2\% in Kano (Rivers, 2002). These differences could be due to cultural and religious differences, the effectiveness of sharia laws in those states or victims do not report the abusers. Prevalence from studies in some African countries varied between $16 \%$ in Cameroun to $67 \%$ in Botswana (Yohannes, 2007), though methodologies used for these studies were different.

\section{Conclusion}

The need for policies enactment cannot be overemphasized to deal with sexual harassment in the identified institution if not yet in place. It is concluded based on the findings of this study that if the trend of SH is not addressed as a matter of urgency, it may negatively affect students' quality of education which might dampen the future of the students' especially women which consequently has dangerous economic effect considering the role of women in nation building.

\subsection{Recommendations}

A more detailed study using qualitative approaches may be needed to understand the difficulties in mental health of the victims of sexual harassment.

\section{Competing Interest Statement}

The authors declare that there are no competing or potential conflicts of interest.

\section{References}

Bondestam, F., \& Lundqvist, M. (2020). Sexual harassment in higher education - a systematic review. European Journal of Higher Education. https://doi.org/10.1080/21568235.2020.1729833

Suleiman, M. S. (2017). Perception of Sexual Harassment among Female Students of Tertiary Institutions in Northern Nigeria. Ife Social Sciences Review, 25(2), 80-89.

Beninger, C. (2013). Combating Sexual Harassment in Schools in Sub-Saharan Africa: Legal Strategies Under 
Regional and International Human Rights Law. African Human Rights Law Journal, 13, 281-301.

Lynch, S. (2013). The Fight against Sexual Harassment in Arab Campuses. Retrieved April 5, 2020, from http://chronicle.com/ article/the-fight-against-sexual-harassment.

Sharma, Y. (2013) Harassment, Sexual Abuse and Corrupt Education World Wide. University World Wide News. Retrieved May 9, 2016, from http://www.universityworldnews. com/articlephp?story

Obasanjo, O. (2012). Education and Development. A Lecture Delivered at the 2012 Graduation Ceremony of University of Nigeria Nsukka, Nigeria January 26th, 2012.

Lei, X., Bussey, K., Hay, P., Mond, J., Trompeter, N., Lonergan, A., \& Mitchison, D. (2019). Prevalence and Correlates of Sexual Harassment in Australian Adolescents. Journal of School Violence, 1-13. https://doi.org/10.1080/15388220.2019.1699800

Attar-Schwartz, S. (2009). Peer sexual harassment victimization at school. American Journal of Orthopsychiatry, 79, 407-420. https://doi.org/10.1037/a0016553

Timmerman, G. (2005). A comparison between girls' and boys' experiences of unwanted sexual behaviour in secondary schools. Educational Research, 47, 291-306. https://doi.org/10.1080/00131880500287641

Wei, H. S., \& Chen, J. K. (2012). Factors associated with peer SH victimization among Taiwanese adolescents. SexRoles, 66, 66-78. https://doi.org/10.1007/s11199-011-0073-7

Lichty, L., \& Campbell, R. (2012). Targets and witnesses: Middle school students' sexual harassment experiences. Journal of Early Adolescence, 32, 414-430. https://doi.org/10.1177/0272431610396090

Ormerod, A., \& Perry, L. (2008). Critical climate: Relations among sexual harassment, climate, and outcomes for high school girls and boys. Psychology of Women Quarterly, 32, 113-125. https://doi.org/10.1111/j.1471-6402.2008.00417.x

Ogbonnaya, L. U., Ogbonnaya, C. E., \& Emma-Echiegu, N. B. (2011). Prevalence of sexual harassment/victimization of female students in Ebonyi State University Abakaliki, southeast Nigeria. Journal of Community Medicine and Primary Health Care, 23(1\&2), 56-57.

Smit, D., \& Du Plessis, V. (2011). Sexual Harassment in the Education Sector. Potchefstroom Electronic Law Journal, 6(14), 173-217. https://doi.org/10.4314/pelj.v14i6.6

Imonikhe, JC Aluede, V. O., \& Idogho, P. (2012). A survey of teacher and students perception of Sexual harassment in tertiary institutions of Edo State Nigeria. Journal of Asian Social Science, 8(1), 268-273. https://doi.org/10.5539/ass.v8n1p268

Eom, E., Restaino, S., Perkins, A. M., Neveln, N., \& Harrington, J. W. (2015). Sexual harassment in middle and high school children and effects on physical and mental health. Clin Pediatric, 54, 430-438. https://doi.org/10.1177/0009922814553430

Petersen, J. L., \& Hyde, J. S. (2013). Peer sexual harassment and disordered eating in early adolescence. Dev Psychol, 49, 184-195. https://doi.org/10.1037/a0028247

Rosenthal, M., Smidt, A., \& Freyd, J. (2016). Still second class: sexual harassment of graduate students. Psychol Women, 40, 364-377. https://doi.org/10.1177/0361684316644838

Bucchianeri, M. M., Eisenberg, M. E., Wall, M. M., Piran, N., \& Neumark-Sztainer, D. (2014) Multiple types of harassment: associations with emotional well-being and unhealthy behaviors in adolescents. $J$ Adolescent Health, 54, 724-729. https://doi.org/10.1016/j.jadohealth.2013.10.205

Chiodo, D., Wolfe, D. A., Crooks, C., Hughes, R., \& Jaffe, P. (2009). Impact of sexual harassment victimization by peers on subsequent adolescent victimization and adjustment: a longitudinal study. J Adolescent Health, 45, 46-52. https://doi.org/10.1016/j.jadohealth.2009.01.006

Olaleye, O. S., \& Ajuwon, A. J. (2012). Prevalence and Factors Associated with Perpetration of Non-Consensual Sex among Students of a Tertiary Institution in Ibadan, Nigeria. African Journal of Reproductive Health December, 16(4), 108.

Bastiani, F., Romito, P., \& Saurel-Cubizolles, M.-J. (2018). Mental distress and sexual harassment in Italian university students. Archives of Women's Mental Health. https://doi.org/10.1007/s00737-018-0886-2

Menon, A., Shilalukey, Ngoma, M. P., Siziya, S., Ndubani, P., Musepa, M., ... \& Serpell, R. (2009). University z Students' Perception of Sexual Harassment: A Case study of the University of Zambia. Med. J. Zambia, 36(2), 
85-91. https://doi.org/10.4314/mjz.v36i2.56060

Arya, S., \& Arya, S. K. A. (2019). Nature, extent, causes and effects of sexual harassment faced by school girls. The Pharma Innovation Journal, 8(11), 44-48.

Bendixen, M., \& Kennair, L. E. O. (2017). Advances in the understanding of same-sex and opposite-sex sexual $\begin{array}{llll}\text { harassment. Evolution } & \text { Bnd Hehavior, 38(5), 591. }\end{array}$ https://doi.org/10.1016/j.evolhumbehav.2017.01.001

Espelage, D. L., Hong, J. S., Rinehart, S., \& Doshi, N. (2016). Understanding types, locations, \& perpetrators of peer-to-peer sexual harassment in US middle schools: A focus on sex, racial, and grade differences. Children and Youth Services Review, 71, 174-183. https://doi.org/10.1016/j.childyouth.2016.11.010

Gewirtz-Meydan, A., \& Finkelhor, D. (2019). Sexual abuse and assault in a large national sample of children and adolescents. Child maltreatment, 1077559519873975. https://doi.org/10.1177/1077559519873975

AAUW Educational Foundation. (2011). Crossing the line: sexual harassment at school. Washington DC: AAUW [Accessed: 08/06/2018] Retrieved from https://www.aauw.org/files/2013/02/Crossing-the-Line-Sexual-Harassment-at-School.pdf

Goodman, M. L., Hindman, A., Keiser, P. H., Gitari, S., Ackerman Porter, K., \& Raimer, B. G. (2020). Neglect, sexual abuse, and witnessing intimate partner violence during childhood predicts later life violent attitudes against children among Kenyan women: Evidence of intergenerational risk transmission from cross-sectional data. Journal of interpersonal violence, 35(3-4), 623-645. https://doi.org/10.1177/0886260516689777

Plummer, C. A. (2006). The discovery process: What mothers see and do in gaining awareness of the sexual abuse of their children. Child Abuse \& Neglect, 30(11), 1227-1237. https://doi.org/10.1016/j.chiabu.2006.05.007

Schaeffer, P., Leventhal, J. M., \& Asnes, A. G. (2011). Children's disclosures of sexual abuse: Learning from direct inquiry. Child abuse \& neglect, 35(5), 343-352. https://doi.org/10.1016/j.chiabu.2011.01.014

Mezie-Okoye, M. M. I., \& Alamina. F. F. (2014). Sexual Violence among Female Undergraduates in a Tertiary Institution in Port Harcourt: Prevalence, Pattern, Determinants and Health Consequences. African Journal of Reproductive Health December, 18(4), 80.

Gaba, S. (2010). Sexual harassment in Nigeria Tertiary Institutions. The Psychologist, 5(8), 319-321.

Imonikhe, J., Aluede, V. O., \& Idogho, P. (2012). A survey of teacher and students perception of Sexual harassment in tertiary institutions of Edo State Nigeria. Journal of Asian Social Science, 8(1), 268-273. https://doi.org/10.5539/ass.v8n1p268

Oni, H. T., Tshitangano, T. G., \& Akinsola, H. A. (2019). Sexual harassment and victimization of students: a case study of a higher education institution in South Africa. African Health Sciences, 19(1). 1478-1485. https://doi.org/10.4314/ahs.v19i1.21

Dastile, N. P. (2004). Victimization of Female students at the University of Venda with Specific Reference to Sexual Harassment and Rape. A Thesis submitted in Partial Fulfilment of the Requirements for the Degree of Master of Arts at the Faculty of Humanities in the University of Pretoria. Pretoria: University of Pretoria.

Ogunbameru, K. A. (2006). Sexual harassment in Nigerian Tertiary Institutions. Ibadan: Spectrums Books Limited.

Effa, E. E., Okokon, E. O., Nwagbara, A. B., \& Bello, S. (2012). Pattern, determinants and mental consequences of sexual violence among female undergraduate students in Calabar, Southern Nigeria. Retrieved from http://svriforum2009.svri.org/presentations/Nwagbara.pdf

Kullima, A. A., Kawuwa, M. B., Audu, B. M., Mairiga, A. G., \& Bukar M. (2010). Sexual Assault against Female Nigerian Students. Afr. J of Reprod Health, 14(3), 189-193.

Iliyasu, Z., Abubakar, I. S., Aliyu, M. H., Galadanci, H. S., \& Salihu, H. M. (2011). Prevalence and correlates of gender-based violence among female university students in Northern Nigeria. Afr. J of Reprod Health, 15(3), 111-119.

Alexander, Y. (2012). Prevalence of Gender Based Violence in Northern Sierra Leone. Technical Report Series; Centre for Accountability and the Rule of Law (CARL-SL). Retrieved from http://www.carl-sl.org

Menick, D. M. (2002). Sexual abuse at schools in Cameroon: results of a survey-action program in Yaounde. Med Trop, 62, 58-62. 
Rivers, R. (2002). Shattered Hopes: Study of sexual abuse of girls. UNICEF Botswana, 34-45.

Yohannes, G. Y. (2007). Prevalence and Factors Related to Gender Based Violence among Female Students of Higher Learning Institutions in Mekelle town, Tigray, Northern Ethiopia (MPH Thesis: Department of Community Health, Addis Ababa University, pp. 23-45).

\section{Copyrights}

Copyright for this article is retained by the author(s), with first publication rights granted to the journal.

This is an open-access article distributed under the terms and conditions of the Creative Commons Attribution license (http://creativecommons.org/licenses/by/4.0/). 